\title{
The Influence of School Leadership and Teacher Professionalism on Learning Innovation at SMP Negeri 32 Oku
}

\author{
Zulkifli ${ }^{*}{ }^{*}$ \\ ${ }^{1}$ Universitas PGRI Palembang \\ *Corresponding author. E-mail: Abizizi84@gmail.com
}

\begin{abstract}
Teachers as the most important component in the learning process must have professional competence in carrying out their functions and responsibilities. The purpose of this study was to determine the effect of principal leadership on learning innovation, to determine the effect of teacher professionalism on learning innovation, and to know the effect of principal leadership and teacher professionalism on learning innovation. This research was conducted at SMP Negeri 32 OKU. The analysis technique used in this research is descriptive quantitative using the ex post facto research design. The population used in this study were 65 teachers of SMP Negeri 32 OKU, and the sampling technique used probability sampling techniques. The results show that: there is an influence of principal leadership and teacher professionalism on learning innovation at SMP Negeri 32 OKU, because the professional competence of teachers, especially in learning innovation, is generally not optimal. Teacher professionalism in the use of instructional media is also considered low. Teachers have not maximally strived to improve professionalism and also do not have sufficient competence to innovate learning in schools. The leadership of the principal is still not optimal in formulating innovations that are expected to bring schools to be superior schools in the future. Indicators show that schools have not been optimal in innovating, especially in the management of learning
\end{abstract}

Keywords: Principal Leadership, Teacher Professionalism and Learning Innovation

\section{INTRODUCTION}

Technological advances today and in the future, especially in the field of information and communication have caused this world to be narrow in scope. The interaction between one nation and another, whether intentional or unintentional, has become increasingly intense.[1][2] Hence, a nation is not left behind by new things that are happening globally so that it can adapt to countries in the world and on the other hand it must also have a strong filter so that the negative globalization influence does not interfere with the life of the nation by upholding character and having a culture. the sublime.

As stated by Gilley, Jerry W., and Eggland, Steven asserted that that one of the important issues with regard to contemporary developments, namely quality improvement, innovation and customer service.[3] Thus, one of the important issues with regard to educational institutions is innovation.
Educational innovation is indeed a necessity in responding to the demands of the internal environment and in response to the external needs of the national education world.[4][5] Hence, the implemented national education system is able to create a new national cultural order that is smarter and more prosperous and advances the nation. Furthermore one of the important components in increasing creativity and intellectuality through innovation in educational institutions is principal leadership.[6] Leaders who are able to manage diversity well will foster and develop innovation in an organization, including in the world of education.

In addition to the leadership of the school principal, in making learning innovations in schools it is also necessary to provide innovative teachers which are marked by: 1) openness to new experiences; 2) flexibility in thinking; 3) freedom in self-expression; 4) respect for fantasy; 5) interest in creative activities; 6) belief in one's own ideas; 7) independence in providing their own considerations [7] From the results of 
observations made by researchers on February 2, 2020 to February 10, 2020 at SMP Negeri 32 OKU, the researchers considered that the professional competence of teachers, especially in learning innovation, was generally not optimal. One of the indicators found by the researchers was that teachers had not been able to develop teaching materials according to learning needs, and the professionalism of teachers in using learning media was also considered low. Teachers have not been able to innovate in combining the media needed to deliver learning materials.

Therefore, teachers as the most important component in the learning process must have professional competence in carrying out their functions and responsibilities. Through high professionalism, teachers will have the ability to innovate according to developments in science and technology which in turn will produce quality education. Thus the leadership of school principals and teacher professionalism have a very important role in encouraging innovation in educational institutions.

From the description that the author has described above the objectives of this study were to determine the effect of principal leadership on learning innovation at SMP Negeri $32 \mathrm{OKU}$, to determine the effect of teacher professionalism on learning innovation at SMP Negeri 32 OKU, and to determine the joint influence of principal leadership and teacher professionalism on innovation. learning at SMP Negeri 32 OKU.

\section{Learning Innovations}

Innovation is an idea or item or thing that doesn't exist yet or already exists but is not yet known to the adopters. Innovation can also be in the form of new methods to improve the quality or quality of an existing program or item. According to the concerning the National System for Research, Development and Application of Science and Technology, innovation is a research, development or engineering activity that aims to develop practical applications of new values and scientific contexts, or new ways of applying science.[8] and existing technology into the product or production process. Innovation is a planned change, which aims to improve practice towards a better state.[9]

Strictly speaking, innovation is something new, which creates a new atmosphere because there are new ways to meet human needs [10] Learning innovation is an idea, item, method that is felt or observed as new to a person or group of people (society) which is used to achieve certain goals in education or solve educational problems. Educational innovation in Indonesia can be seen from four aspects, namely educational goals, education and teaching structure, curriculum and teaching methods and changes to aspects of education.

\section{Principal Leadership}

1. Leadership

Leadership is an effort to influence people by providing motivation and direction so that they want to work together to achieve the goals that have been set together.[11] Leadership is a process of influence influencing between individuals or people in a particular situation through a process of communication directed to achieve a specific goal.[12][13] Hence, Leadership is the existence of individual behavior in interaction with social systems to achieve a goal. Achieved or not the purpose of the organization is highly dependent on the leadership used by the leader. Leadership behavior is generally referred to as a number of specific actions, in which the leader is involved in ways of directing and coordinating group member workers

2. Leadership Style

According to Thoha Leadership style is a consistent pattern of behavior shown by the leader and recognized by others when the leader tries to influence others.[14] Leadership styles include autocratic leadership styles, democratic leadership styles, and permissive leadership styles. In the context of the leadership of educational institutions, the principal can use this leadership style to influence all subordinates in the school he leads. However, the right leadership style to motivate school principals is a democratic leadership style. Leadership style is a norm of behavior used by a person when that person tries to influence the behavior of others as he sees it.

3. Principal

Principal comes from two words, namely head and school. the word head can mean the chairman or leader in an organization or an institution. Meanwhile school is an institution where it is a place to receive and give lessons. The principal is the highest leader in an educational institution who is responsible for everything related to the smooth running of the school for the realization of the school's goals.[15] A school principal should be able to ensure that everything in the management of educational institutions is running well, including planning and implementing curriculum, providing and utilizing teacher resources, recruiting student resources, school collaboration with parents, and quality graduates.[16][17] The principal as a vital element for effectiveness in educational institutions determines the level of quality of the institution, the principal is likened to the education commander who carries out the control function of various patterns of teaching and educational activities in it.

c. Teacher Professionalism

Teacher professionalism is the ability of teachers to carry out their main duties as educators and teachers including the ability to plan, conduct and carry out learning evaluations. [18] In principle, every teacher 
must be periodically supervised in carrying out their duties. If the number of teachers is large enough, the principal can ask for help from a representative or a senior teacher for supervision. The success of the principal as a student is marked by the awareness and skills to carry out duties responsibly. Professionalism comes from an adjective which means making a living and as a noun which means people who have expertise, such as teachers, doctors, judges and so on. In other words, work that is professional in nature is work that can only be done by those who are specially prepared for it and not work done by those who are unable to get another job.

d. Characteristics of Teacher Professionalism

$$
\text { Professionalism mentions }
$$

several characteristics of teacher professionalism as follows 1) identifying deficiencies, weaknesses, difficulties, or problems experienced by him; 2) establish a program to increase the ability of teachers to overcome deficiencies, weaknesses, difficulties; 3) formulating the objectives of the learning program; 4) determine and design learning materials and media; 5) establish forms and develop assessment instruments; 6) compile and allocate learning programs to conduct assessments; 7) carry out follow-up to students.[19] An educator must have the following characteristics 1) An educator must have professional maturity, namely regarding science, loving his students; 2) An educator must have a stable self, namely the ability to protect himself from prohibited acts; 3 ) An educator must have stable social maturity, namely old age, dignity, courtesy, patience so that he can foster effective cooperation with students.

Some previous studies, for instance Information Technology-Based Learning Innovation in Improving the Quality of Vocational Education (Study at PGRI 3 Vocational High School Malang). [9] The results of the study indicate that there are several forms of information technology-based learning innovations in improving the quality of vocational education in these schools, among others; (1) Provision of IT-based educational facilities; (2) Developing the capacity of teaching staff in the IT field; (3) Cooperation with the industrial world in providing IT-based educational facilities; (4) Utilization of Tablet Computers in Learning; (5) Enrolling students in competitions in the IT field. There are several supporting factors that influence, among others; (1) Great support Great support from the Principal of SMK PGRI 3 Malang; (2) Availability of Wi-Fi Hot Spot networks; (3) Good cooperation with the industrial world. In addition, there are several inhibiting factors that have a negative and hindering impact, among others; (1) Uneven ability of teaching staff related to the use of Information Technology facilities; (2) Unavoidable possibility of damage or interference to the supporting equipment.

Furthermore, Ulansari with the title
Information Technology-Based Learning Innovation in Improving Service Quality at Smart Insani High School, Central Lampung. [20] 80\% (percent) of Smart Insani Senior High School has implemented this innovation because there are still 10 teachers who have not mastered computers and still lack electricity power, internet, extranet and some inadequate facilities and infrastructure, for example computers and wifi which are still lacking. With the innovation carried out at SMA Smart Insani Central Lampung this school is able to attract people in Central Lampung with good quality and service and is able to create smart and competitive students in the world of education, this is evidenced by the number of alumni accepted at PTN (state universities). And the attraction of the innovation carried out at Smart Insani High School is that this school uses 3 languages that are applied daily in schools, namely English, Indonesian and Arabic which have only been done in private schools in Central Lampung. Teacher professionalism towards learning innovation. Other research entitled The Influence of Principal Leadership, Achievement Motivation and School Culture on Teacher Professional Competence in MAS in Natar District. [21] The result show that there was a positive and significant influence of achievement motivation on teacher professional competence; (3) there is a positive and significant influence of school culture on teacher professional competence; (4) there is a positive and significant influence of school principal leadership, achievement motivation and school culture on teacher professional competence.

Relevant with other research Supriadi (2018) the title Implementation of Innovation Management and Teacher Creativity in Improving Learning Quality. [22]. The results of the study inform that the implementation of innovation management and teacher creativity in improving the quality of learning can run well because every teacher always has the right effort in transferring knowledge according to the character of students and teaching time. The obstacle is the lack of supporting media for learning, both supporting the progress of teachers and students, so that it can hinder the quality of learning in this school.

\section{METHODS}

This research is a quantitative research. This research method uses the method of partial correlation; partial correlation is used for analysis or hypothesis testing. The design in this study used an ex post facto research design. The population in this study were all teachers of SMP Negeri 32 OKU, totaling 65 people. The sampling technique in this study uses probability sampling techniques. The sample in this study amounted to 65 respondents consisting of all teachers of SMP Negeri 32 OKU. 


\section{RESULTS AND DISCUSSION}

Research hypothesis testing has been carried out for each hypothesis in succession starting from the first hypothesis about whether there is an effect of the principal's leadership on learning innovation. The second hypothesis is whether there is an effect of teacher professionalism on learning innovation. The third hypothesis is whether there is a joint influence of principal leadership and teacher professionalism on learning innovation. For more details regarding the description of the results of testing the hypothesis for each of the above variables, the researchers describe it as follows:

\section{The Effect of Principal Leadership on Learning Innovation}

Data processing on the relationship between variables shows that the correlation value (r) of the relationship between the principal's leadership and learning innovation results in a correlation (r) of 0.723 , thus there is a positive relationship between variables, meaning that if the leadership variable of the Principal increases or is increased it will be followed by variable strengthening. learning innovation. The coefficient of determination (r) of 0.616 or $72.69 \%$ is a variation of the increase in the learning innovation variable which can be explained by the Principal's leadership variable of $72.69 \%$, thus other factors outside the two variables are $27.30 \%$. The probability of the outcome $[\rho=0.000$ $<\alpha=0.05]$ then there is an influence of the principal's leadership on learning innovation.

The constant value of 4.107 is the pure value of learning innovation without being influenced by the principal's leadership variable, while 0.788 is the amount of learning innovation if the principal's leadership changes by 3.205. While the regression value $(\beta)$ is 0.736 , thus there is a positive contribution generated by the learning innovation variable, meaning that the principal leadership variable increases of 1 point, it will be followed by a learning innovation of 0.736 .

The results of data processing on the variable of the influence of the principal's leadership on learning innovation obtained the $t$ value of 13,773 , where the $t$ table for $\mathrm{n}=90$ is 2.00 thus [ $\mathrm{t}$ count 13,773> $\mathrm{t}$ table 2.00] then (Ho) is rejected and (Ha) accepted means that there is an influence from the principal's leadership on learning innovation.

\section{The effect of teacher performance on student achievement.}

The results of data processing on the variable (r), the relationship between teacher professionalism and learning innovation, obtained a correlation ( $r$ ) of 0.725 , thus there is a relatively strong positive relationship between variables, meaning that if the variable teacher professionalism increases or is increased it will be followed by strengthening of learning innovation or vice versa.

The value of the determinant coefficient $(\mathrm{r}$ ) amounted to 0.586 or $58.60 \%$ of the professionalism of teachers towards learning innovation. Thus the variable teacher professionalism can increase learning innovation by $57.58 \%$ and the remaining $30.30 \%$ is influenced by other factors that are not studied. probability of outcome $[\rho=0.00<\alpha=0.05]$ then there is an effect of teacher professionalism on learning innovation.

The constant value of -3.332 is the pure value of the learning innovation variable without being influenced by the teacher professionalism variable, while the regression value $(\beta)$ is 0.625 , thus there is a positive contribution generated by the learning innovation variable, meaning that if the variable teacher professionalism increases by 1 point it will be followed by an increase. learning innovation variable of 0.625 .

The results of data processing on the variable teacher professionalism on learning innovation, the value of $t$ count is 12,034 , where the t table is 2.00 , thus [tcount 12.034> 2.00] then (Ho) is rejected and $(\mathrm{Ha})$ is accepted, meaning that there is an influence of teacher professionalism on innovation learning, can be accepted because the truth has been tested.

\section{The Influence of Principal Leadership and Teacher Professionalism on Learning Innovation.}

Data processing on the variable of the influence of principal leadership and teacher professionalism on learning innovation resulted in a correlation (r) of 0.706 , thus there is a relatively strong positive relationship between variables, meaning that if the principal leadership variable and teacher professionalism increase, learning innovation will increase or vice versa.

The value of the determinant coefficient ( $r$ ) is 0.724 or $81.40 \%$, thus variations in learning innovations can be explained by the principal's leadership and teacher professionalism of $81.40 \%$, thus other factors outside the two variables are $16.60 \%$. The probability of the outcome $[\rho=0.00<\alpha=0.05]$ means that the principal's leadership and teacher professionalism have a significant relationship with learning innovation.

The constant value of $-10,011$ is the pure value of the learning innovation variable without being influenced by the principal's leadership and teacher professionalism, thus there is a positive contribution made by the principal's leadership variable and teacher professionalism towards learning innovation, meaning that the principal's leadership and teacher professionalism increase by 1 point then will be 
followed by learning innovation with a regression value of 0.432 .

Based on the calculation results obtained Fcount is 188,186 with a significant level of $0.00<0.005$, so the regression model can be used to predict $(\mathrm{Y})$. To test the significance of (X1), (X2), against (Y), the following formula is used:

If Fcount $>$ Ftable, then the hypothesis is accepted If Fcount <Ftable, then the hypothesis is rejected It turns out that if Fcount 188,186> Ftable 1.90, then the hypothesis is accepted

It turns out that based on the results of the calculation, it is known that Fcount 188.186> Ftable 1.80, so it is significant. In other words, the hypothesis that the researcher proposes, namely "Is there an influence of principal leadership and teacher professionalism on learning innovation" can be accepted because it has been verified.

The finding of the influence of principal leadership and teacher professionalism on learning innovation known that there is an influence of the principal's leadership on learning innovation. The better the leadership of the principal, the student learning innovation will increase. In his function as the principal of SMP Negeri 32 OKU, he is able to provide direction and provide encouragement to teacher professionalism in order to be able to increase learning innovation for students of SMP Negeri 32 OKU.

The principal is the driving force, determines the direction of school policy, which will determine how to form good learning innovations for students so that the creation of good learning innovations will result in more creative education so as not to make students learn to be boring. The principal has the full right to assist and provide teacher direction in order to shape teacher professionalism and achieve good student innovation.

With the afore mentioned leadership, it would be very beneficial for the principal of SMP Negeri 32 OKU to carry out his duties as a better leader so as to increase teacher professionalism in order to create learning innovations at SMP Negeri 32 OKU.

Other finding known that there was an influence of teacher professionalism on learning innovation, meaning that professional teachers, learning innovation is increasing.[23] As a step to create professional teachers, coaching is treated in an integrated manner in full cooperation between the working groups, as well as the head of the school and the community. In connection with this, effective coaching, according to Cook, M. J., \& Poole, L. (2011) includes 5 (five) important components, namely: Teaching and Learning Activities, Educational Management, Books and Learning Tools, School performance and education, and Community Participation.
Professional teachers have the potential to rely on both in terms of quality and quantity. In general, there are three types of professional competence for professional education personnel, namely personal competence, professional competence and social competence.[25] Therefore, these three competencies are used as benchmarks for the success of education and education personnel. The characteristics of professional teachers will be reflected in the performance of the implementation of assignments which are marked by expertise in both material and method.[26] Expertise possessed by professional teachers is expertise obtained through a specially programmed education and training process.

Based on this description, it is very clear that teacher professionalism will have an influence on learning innovation, this is because with the dull professionalism of a teacher it will lead to good and creative learning innovations for students so that the teaching and learning process becomes interesting and not boring.

\section{CONCLUSION}

Based on the results of research and discussion that researchers have done, the researchers conclude as follows: With the movement of the principal's leadership is very influential on learning innovation, it means that the better the principal is in carrying out his leadership, the better the student's innovation will be. Teacher professionalism affects learning innovation. This means that the better the professionalism of the teacher in teaching, the better the student's innovation will be so that it always creates new things every day. Principal leadership and teacher professionalism affect student innovation, meaning that student innovation is very influential with the principal's leadership and also affects teacher professionalism, because basically teachers must be able to be creative and creative in the teaching and learning process so that it is not boring.

Other suggestion for the principal is a central figure in the school where he must be able to improve teacher professionalism towards student learning innovation at SMP Negeri 32 OKU. Furthermpre, teacher professionalism must be maintained and improved, because teachers of SMP Negeri 32 OKU are still less professional in carrying out their duties. Therefore, the teacher must be able to open up insights and create interesting ideas so that the teaching and learning process does not feel boring.

\section{REFERENCES}

[1] Wawan, W., Marsigit, M., Ningsih, E. F., Widyawati, S., Kusumaningtyas, W., Mahmudi, M., \& Setiawan, A. (2018). Technology-Integrated Collaborative Learning: Convenient Al-ternative 
in Developing the Problem Solving Capability and Positive Attitude. International Journal of Engineering \& Technology, 7(3.2), 737-740.

[2] Khusna, A. A., Sari, Y. A., \& Tohir, M. (2019). Developing E-Learning Worksheet Based Information Technology For English Learning. Attractive: Innovative Education Journal, 1(1), 14-39.

[3] Gilley, Jerry W., and Eggland, Steven A., (2010), Principles Of Human Resource Development, California New York: Addison-Wesley Publishing Company

[4] Khadijah, I. (2021). The Competency of Science Teachers in Implementation of Online Learning In Covid-19 Pandemic Period at SMPN 2 Kramatwatu Serang.Bulletin of Science Education, 1(1), 60-67.

[5] Syafaruddin, S., Asrul, A., Mesiono, M., Wijaya, C., \& Usiono, U. (2016). Inovasi pendidikan: suatu analisis terhadap kebijakan baru pendidikan.

[6] Irianisyah, S., Harapan, E., \& Houtman, H. (2020). Supervisi Kepala Sekolah Dalam Penggunaan Media Pembelajaran di Sekolah Dasar. Attractive: Innovative Education Journal, 2(3), 1-7.

[7] Suyatno. (2014). Menjelajah Pembelajaran Inovatif. Sidoarjo: Masmedia Buana. Pustaka.

[8] UU Republik Indonesia No 18 tahun 2002 tentang Sistem Nasional Penelitian, Pengembanggan, dan Penerapan Ilmu Pengetahuan dan teknologi

[9] Eliyasni, R., Kenedi, A. K., \& Sayer, I. M. (2019). Blended Learning and Project Based Learning: The Method to Improve Students' Higher Order Thinking Skill (HOTS). Jurnal Iqra': Kajian Ilmu Pendidikan, 4(2), 231-248.

[10] Ancok, D. (2012). Psikologi kepemimpinan dan inovasi. Jakarta: Erlangga.

[11] Sanjaya, W. (2010). Strategi Pembelajaran Berorientasi Standar Proses. Pendidikan. Jakarta : Prenada Media Group.

[12] Sarni, S., \& Muslimah, M. (2021). The Commendable Leadership in Islamic Perspective. Bulletin of Pedagogical Research, 1(1), 163-173.

[13] Umam, W. (2020). Kepemimpinan Kiai dalam Mengembangkan Pondok Pesantren. Attractive: Innovative Education Journal, 2(3), 61-69.

[14] Thoha, M. (2010). Kepemimpinan Dalam Manajemen, Jakarta : Rajawali Pers

[15] Asnawan, A. (2021). Enhancement Integrated Quality Management in Islamic Education Institutions. Bulletin of Science Education, 1(1), 42-49.
[16] Romlah, O. Y., \& Latief, S. (2021). Empowering the Quality of School Resources in Improving the Quality of Education. Bulletin of Science Education, 1(1), 37-41.

[17] Suhono, S., \& Sari, D. A. (2020). Developing Students' Worksheet Based Educational Comic for Eleventh Grade of Vocational High School Agriculture. Anglophile Journal, 1(1), 29-40.

[18] Iqbal, M. (2019). Penerapan Kompetensi Pedogogik Dalam Meningkatkan Mutu Pembelajaran Guru Pendidikan Islam. Attractive: Innovative Education Journal, 1(1), 111-143.

[19] Sardiman. A.M, (2014). Interaksi dan Motivasi Belajar Mengajar. Jakarta: Rajawali. Pers.

[20] Ulansari, L. U. (2015). Inovasi pembelajaran Berbasis Teknologi Informasi dalam Meningkatkan Mutu Pendidikan Kejuruan (Studi pada Sekolah Menengah Kejuruan PGRI 3 Malang). Jurnal Administrasi Publik, 3(11), 18511856.

[21] Hotimah, H. (2019). Pengaruh Kepemimpinan Kepala Sekolah, Motivasi Berprestasi Dan Budaya Sekolah Terhadap Kompetensi Profesional Guru Di MAS Se-Kecamatan Natar (Doctoral dissertation, Universitas Lampung).

[22] Supriadi, D. (2018). Implementasi Manajemen Inovasi dan Kreatifitas Guru dalam Meningkatkan Mutu Pembelajaran. Journal of Education Management \& Administration Review, 1(2), 125132.

[23] Bafadal, I. I., Bafadal, I., Sobri, A. Y., Nurabadi, A., \& Gunawan, I. (2019, December). Standards of Competency of Head of School Beginners as Leaders in Learning Innovation. In 5 th International Conference on Education and Technology (ICET 2019) (pp. 13-18). Atlantis Press.

[24] Cook, M. J., \& Poole, L. (2011). Effective coaching. McGraw-Hill Education.

[25] Hakim, A. (2015). Contribution of competence teacher (pedagogical, personality, professional competence and social) on the performance of learning. The International Journal of Engineering and Science, 4(2), 1-12.

[26] Supriyanto, A., Hartini, S., Syamsudin, S., \& Sutoyo, A. (2019). Indicators of professional competencies in research of Guidance and Counseling Teachers. Counsellia: Jurnal Bimbingan dan Konseling, 9(1), 53-64. 